\title{
Combustion characteristics of various fuels during research octane number testing on an instrumented CFR F1/F2 engine
}

The Cooperative Fuels Research (CFR) engine is the long-established standard for characterization of fuel knock resistance in spark-ignition internal combustion engines. Despite its measurements of RON and MON being widely used, there is little understanding of what governs the CFR octane rating for fuels of various chemical compositions compared to primary reference fuels (iso-octane and n-heptane). Detailed combustion characteristics were measured on a highly instrumented CFR F1/F2 engine during RON testing of fuels with significantly different chemical composition. The results revealed differences in the cylinder pressure and temperature conditions, as well as knocking characteristics.

Key words: octane, gasoline, fuel, auto-ignition, knock

\section{Introduction}

The Waukesha CFR F1/F2 octane rating engine is the international testing standard for measuring fuel octane number. Two octane rating methods are commonly used for automotive spark-ignition engine fuels, namely the research method and motor method (ASTM D2699 and ASTM D2700, respectively) [1, 2]. Research octane number (RON) is the test measurement most commonly reported in the sale of automotive gasolines around the world, although most countries also regulate a minimum motor octane number (MON). In North America, gasoline fuels are marketed and sold based on the average of the RON and MON, giving rise to the terms pump octane number (PON) or antiknock index (AKI), as seen in Equation 1.

$$
\mathrm{AKI}=(\mathrm{RON}+\mathrm{MON}) / 2
$$

The engine operating conditions of these two ASTM test methods can be found in Table 1 .

Table 1. Engine operating conditions of RON and MON tests $[1,2]$

\begin{tabular}{|l|c|c|}
\hline Test & RON & MON \\
\hline ASTM method & D2699 & D2700 \\
\hline Engine speed $(\mathrm{rpm})$ & 600 & 900 \\
\hline Intake air temperature $\left({ }^{\circ} \mathrm{C}\right)$ & $\begin{array}{c}\text { Based on baro- } \\
\text { metric pressure }\end{array}$ & 38 \\
\hline Mixture temperature $\left({ }^{\circ} \mathrm{C}\right)$ & Not controlled & 149 \\
\hline Spark timing $\left({ }^{\circ}\right.$ aTDC $)$ & -13 & $\begin{array}{c}\text { Based on com- } \\
\text { pression ratio }\end{array}$ \\
\hline Coolant temperature $\left({ }^{\circ} \mathrm{C}\right)$ & 100 & 100 \\
\hline
\end{tabular}

Initially the MON condition, with higher mixture temperature entering the engine and higher engine speed, was designed to be more representative of "higher severity" engine operation when compared to early vehicle road octane number testing. However, with the current trend of engine down-sizing and boosting, the cylinder pressures and temperatures common of modern turbocharged gasoline direct injection (GDI) engines are more similar to, if not beyond, the relatively lower temperature and higher pressure RON conditions [3, 4]. For this reason, and because of its more widely accepted use, the current study will focus on the cylinder combustion and engine operation conditions of the RON test method (ASTM D2699).

\section{Experimental setup}

\subsection{Argonne CFR F1/F2 engine}

In this work, several gasoline-like fuel blends were tested under the standard ASTM D2699 RON method test conditions on a Waukesha CFR F1/F2 octane rating engine. The RON method engine operating conditions were shown in Table 1 and the geometry of this engine can be found in Table 2.

Table 2. Waukesha CFR F1/F2 engine geometry

\begin{tabular}{|l|c|}
\hline Combustion chamber & Cast iron, flat "pancake" \\
\hline Compression ratio (-) & Adjustable 4:1 $-18: 1$ \\
\hline Bore x Stroke (inches) & $3.25 \times 4.5$ \\
\hline Displacement $\left(\right.$ inch $\left.^{3}\right)$ & 37.33 \\
\hline Intake valve & $180^{\circ}$ shroud, no rotation \\
\hline Exhaust valve & No shroud, rotating \\
\hline Valve overlap & Positive 5 CAD \\
\hline Piston rings & $\begin{array}{c}\text { Top: Chrome-plated, straight-sided } \\
\text { Middle (3): Ferrous, straight-sided } \\
\text { Oil (1): Cast iron, one-piece, slotted }\end{array}$ \\
\hline Fuel system & $\begin{array}{c}\text { Carbureted, adjustable level float } \\
\text { chamber A/F control }\end{array}$ \\
\hline Ignition & Capacitive discharge coil to spark \\
\hline
\end{tabular}

The typical CFR engine setup consists of several engine controls and basically two measurements: carburetor sight glass fuel level and knockmeter knock units. These controls and measurements can be seen in Table 3 .

Table 3. Waukesha CFR F1/F2 engine controls and measurements

\begin{tabular}{|l|c|}
\hline \multicolumn{2}{|c|}{ Controls } \\
\hline Engine speed & Pulley drive ratio \\
\hline Intake air rel. humidity & Refrigerated intake air conditioner \\
\hline Intake air temperature & Air heater upstream of carburetor \\
\hline $\begin{array}{l}\text { Mixture temperature } \\
\text { MON only) }\end{array}$ & $\begin{array}{c}\text { Mixture heater downstream of carburetor } \\
\text { Compression ratio }\end{array}$ \\
\hline Spark timing & $\begin{array}{c}\text { Worm gear around cylinder to adjust } \\
\text { cylinder head height }\end{array}$ \\
\hline Air-fuel ratio & Mechanically adjusted \\
\hline \multicolumn{2}{|c|}{ Carburetor bowl height } \\
\hline Relative air-fuel ratio & Measurements \\
\hline Relative knock & Knockmeter system knock units (KU) \\
\hline
\end{tabular}

As shown in Table 3, the measurements obtained from standard ASTM RON (or MON) testing is limited to a 
relative air-fuel ratio (dependent on carburetor jet sizes) and a relative measurement of combustion knock (measurement scale is tuned based on \pm 1 octane number of the test fuel). In order to get more detailed and absolute measurements of engine combustion characteristics and operating conditions, several instrumentation upgrades common for modern engine combustion research have been add to the CFR engine at Argonne National Laboratory. Important to note is that all of these measurement upgrades have taken place without affecting the geometry or performance of the CFR engine during standard octane testing. A list of the upgraded measurements and instrumentation are provided in Table 4.

Table 4. Modern engine combustion research measurement and instrumentation upgrades to the Argonne CFR F1/F2 engine

\begin{tabular}{|l|c|}
\hline \multicolumn{2}{|c|}{ Crankshaft angle-based measurements } \\
\hline Crank-angle based DAQ & AVL IndiCom \& crankshaft encoder \\
\hline Spark timing & Coil wire current clamp \\
\hline Intake pressure & $\begin{array}{c}\text { Kulite high-speed 2.0 bara pressure } \\
\text { transducer }\end{array}$ \\
\hline Exhaust pressure & $\begin{array}{c}\text { Kulite water-cooled high-speed 3.5 } \\
\text { bara pressure transducer }\end{array}$ \\
\hline Cylinder pressure Time-based measurements \\
\hline \multicolumn{2}{|c|}{ LabVIEW } \\
\hline Time-based DAQ & Low-speed pressure transducer \\
\hline Intake pressure & Low-speed pressure transducer \\
\hline Exhaust pressure & $\begin{array}{c}\text { K-type thermocouples } \\
\text { Intake, mixture, exhaust, } \\
\text { coolant, and oil temperature }\end{array}$ \\
\hline Fuel rate & Coriolis meter \\
\hline Lambda & AVL SESAM FT-IR \\
\hline Emissions & AVL i60 emissions bench \\
\hline ASTM knock units & Data-logged knockmeter signal \\
\hline
\end{tabular}

To measure absolute air-fuel ratio, a wide-band lambda sensor was installed in the standard ASTM exhaust line between the exhaust port and the exhaust surge tank. In conjunction with the Coriolis fuel rate meter or emissions measurements, an air flow rate can be estimated. The lambda sensor will also be used to analyze the knockmeter response to lambda changes above and below that of peak knock. In addition to the ASTM knockmeter, which is a relative measurement based on the knocking characteristics of primary reference fuels (PRF) within one octane number of the test fuel, it is possible to measure absolute characteristics of the knocking combustion using a cylinder pressure transducer. While the spark plug pressure transducer is not as accurate of ringing combustion, it allows for some general analyses of the cylinder pressure and combustion characteristics between fuels while still measuring with the ASTM standard knockmeter simultaneously. In this paper, measurements and analyses will be discussed from the wide-band lambda sensor, Coriolis fuel rate meter, ASTM knockmeter, and simultaneously with the spark plug cylinder pressure transducer.

\subsection{Test fuels}

In this work, four fuels all having approximately 98 RON have been analyzed during standard RON test conditions. Two fuels are mostly iso-paraffinic with no ethanol. The "PRF98" fuel is simply a primary reference fuel (PRF) of $98 \% \mathrm{v}$ iso-octane and $2 \% \mathrm{v}$ n-heptane, while the "RON98Alk" fuel is an alkylate gasoline of approximately
$75 \% \mathrm{v}$ iso-octane, $20 \% \mathrm{v}$ other iso-paraffins, $3 \% \mathrm{v}$ n-butane, and a mixture of other families of hydrocarbons at lower concentrations. Two fuels were also tested with $30 \% \mathrm{v}$ ethanol (E30). The "PRF71E30" fuel is composed of 70\%v PRF 71 (71\% iso-octane, 29\% n-heptane) and 30\%v ethanol, while the "RON98E30" is a $30 \% \mathrm{v}$ ethanol full-boiling range gasoline containing paraffins $(12.9 \% \mathrm{v})$, iso-paraffins $(27.6 \% \mathrm{v})$, aromatics $(13.8 \% \mathrm{v})$, naphthenes $(7 \% \mathrm{v})$, and olefins $(5.6 \% \mathrm{v})$. In this way, two non-ethanol highly isoparaffinic fuels could be compared to two fuels with $30 \% \mathrm{v}$ ethanol with blendstocks from either a highly iso-paraffinic fuel (PRF71) or a full-boiling range gasoline. The RON98Alk and RON98E30 fuels were prepared by Gage Products Company, while the PRF98 and PRF71E30 fuels were blended within the Argonne CFR engine test cell using a gravimetric method. The details of the test fuels can be found in Table 5 .

Table 5. Properties of test fuels examined

\begin{tabular}{|l|c|c|c|c|}
\hline Fuel & PRF98 & RON98Alk & PRF71E30 & RON98E30 \\
\hline RON (-) & 98.0 & 97.8 & 97.8 & 97.4 \\
\hline MON (-) & 98.0 & 96.6 & - & 86.6 \\
\hline Sensitivity (-) & 0 & 1.4 & - & 10.8 \\
\hline HoV $(\mathrm{kJ} / \mathrm{kg})$ & 308 & 309 & 519 & 536 \\
\hline LHV (MJ/kg) & 43.3 & 44.5 & 39.3 & 38.2 \\
\hline A/F Ft $_{(-)}$ & 15.1 & 15.1 & 13.1 & 12.9 \\
\hline Paraffin (\%v) & 2 & 3 & 20 & 12.9 \\
\hline I-Paraffin (\%v) & 98 & 95.8 & 50 & 27.6 \\
\hline Aromatics (\%v) & - & 0.7 & - & 13.8 \\
\hline Naphthenes (\%v) & - & 0.02 & - & 7.0 \\
\hline Olefins (\%v) & - & 0.08 & - & 5.6 \\
\hline Oxygenates (\%v) & - & - & 30 & 30.4 \\
\hline
\end{tabular}

The testing methodology for each fuel followed ASTM D2699 for determination of fuel RON. The engine was initially warmed up for an hour under knocking conditions typical of a RON 98 test fuel. This means the compression ratio and intake air temperature (upstream of the carburetor) was set based on ASTM D2699 to compensate for that day's barometric pressure and a fuel octane rating of 98 . After one hour of warm-up at standard knocking conditions, intake and exhaust valve lash was verified or adjusted and the "Model 501-C Detonation Meter" (in this paper referred to simply as "knockmeter") was calibrated for standard knock on a PRF 98 fuel and spread of 12 to 15 knock units (KU) higher and lower than standard knock $(50 \mathrm{KU})$ for the corresponding decrease or increase of PRF test fuel by one octane number $(\mathrm{ON})$.

After proper engine warmup and knockmeter calibration for a range of 97 to $99 \mathrm{RON}$ fuels, the peak knocking lambda condition was found for each fuel by performing a lambda sweep from 0.8 to 1.0. Crankshaft angle-based and time-based measurements were recorded and are compared in this work.

\section{Results and discussion}

\subsection{Lambda sweeps}

Fig. 1 shows the knockmeter measurements during lambda sweeps from 0.8 to 1.0 lambda with each fuel. The peak knocking lambda was approximately 0.89 for the nonethanol highly iso-paraffinic fuels and approximately 0.93 for both the E30 fuels. This sort of detailed peak knocking 
lambda information is not available in standard RON or MON rating tests because standard CFR engine installations do not have a lambda sensor installed. Despite the differences in the pre-ethanol blendstocks, both E30 fuels had a similar peak knocking lambda. The effect of ethanol to increase the peak knocking lambda (less rich) is not completely clear at this time. However variations in fuel blend properties that could influence this result, which will be examined in future work, with increased ethanol include the following possibilities: adiabatic flame temperature, laminar flame speed, stoichiometric air-fuel ratio, engine load, damköhler number, and Rayleigh number.

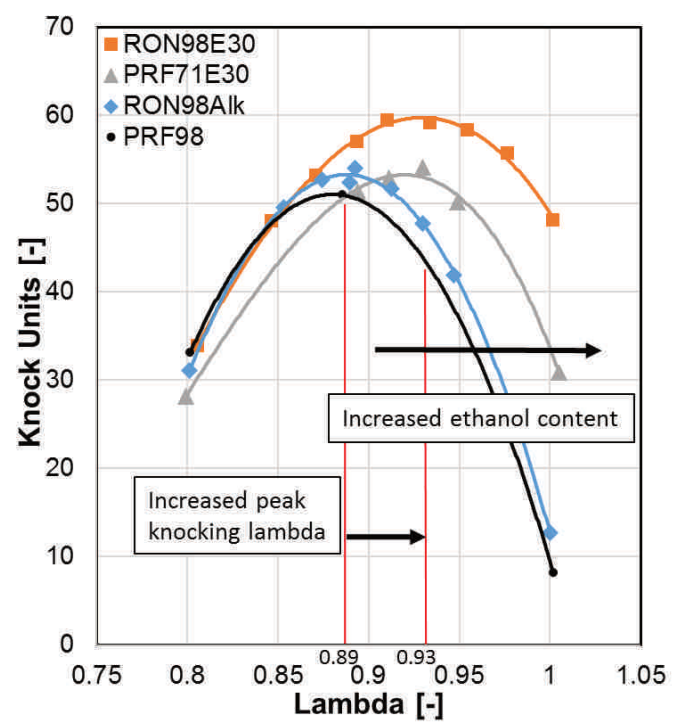

Fig. 1. ASTM knockmeter readings for lambda sweep from 0.8 to 1.0 for each fuel

The RON98E30 fuel, with a full boiling-range gasoline blendstock, measured slightly higher knock units at peak knocking lambda than the other three fuels. This resulted in an actual RON rating of 97.4. The RON98Alk and PRF71E30 fuels also produced slightly higher knocking than the PRF98, thus producing a RON rating of 97.8 . However, this is within the ASTM 2699 standard deviation of $\pm 0.25 \mathrm{ON}$ from the $98.0 \mathrm{RON}$ target (for RON 90 to 100).

It is interesting to see that the fuels had knockmeter measurements which were more similar at 0.8 lambda than at less-rich conditions closer to stoichiometry. The highly iso-paraffinic PRF98 and RON98Alk fuels produced very similar knockmeter response to lambda across the sweep, while the level of knock did not decrease as fast for the E30 fuels at stoichiometry. Future tests will add a small amount of ethanol to the RON98E30 fuel in order to obtain RON levels more similar to the others. As discussed in ASTM D2699, it should also be noted that the Meter 501-C Detonation Meter loses linearity for $<20 \mathrm{KU}$ or $>80 \mathrm{KU}$.

\subsection{Engine operation at RON rating conditions}

As shown in Fig. 1, the lambda of peak knocking was higher for the E30 fuels. In Fig. 2, the engine fueling rate (FR) is shown along with each fuel's peak knocking lambda. Despite the less-rich lambda for the E30 fuels, they actually had higher fuel rate. Looking back to Table 5, it is observed that it was because of the significantly reduce stoichiometric air-fuel ratio $\left(\mathrm{A} / \mathrm{F}_{\mathrm{st}}\right)$ that the fuel rate for the E30 fuels was actually increased.

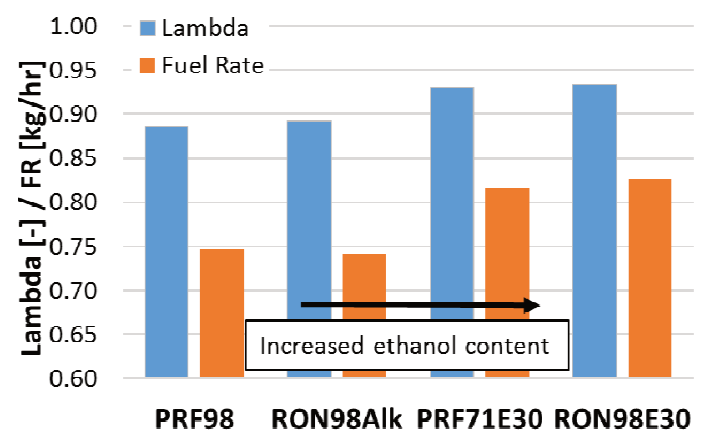

Fig. 2. Lambda and fuel rate (FR) at RON rating conditions for each fuel

Due to a combination of increased fuel rate and higher heat of vaporization (HoV), the E30 fuels had a significantly reduced mixture temperature entering the intake port (downstream of the carburetor) during RON rating. Fig. 3 shows the reduction in mixture temperature by 8 to $13^{\circ} \mathrm{C}$, from the iso-paraffinic fuels to the E30 fuels. While the HoV of the RON98E30 was higher than the PRF71E30, it is likely that the differences in the pre-ethanol fuel blends did not allow for all of the fuel components to be completely evaporated before entering the intake port. This can also be observed in the lower temperature reduction between upstream and downstream of the carburetor (Carb. $\Delta \mathrm{T}$ ) for the RON98E30 fuel. Work by Foong has gone into greater detail in analyzing the effects of increased ethanol and HoV on the RON rating method because of this reduction to the mixture temperature entering the engine [5-7].

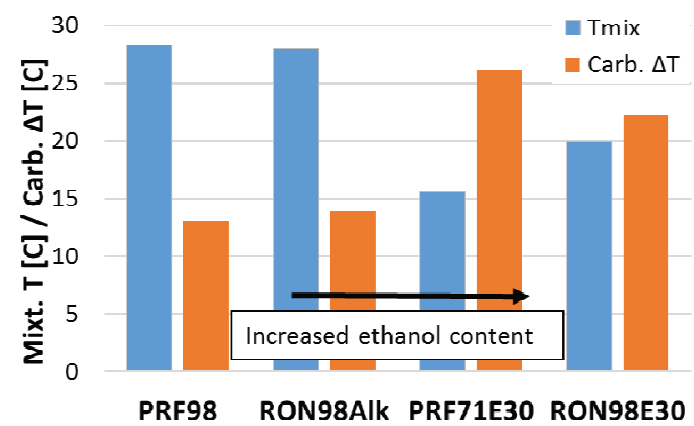

Fig. 3. Mixture temperature after the carburetor and corresponding temperature drop across the carburetor

Focusing on the engine operating conditions of peak knock for each fuel, the gross indicated mean effective pressure (IMEPg) is shown in Fig. 4. As shown in Fig. 5, the less-rich peak knocking lambdas of the E30 fuels allowed for more efficient engine operation and higher engine load during RON test conditions. The increased fuel rates with the E30 fuels does not seem to be the cause of increased load, being that the total fuel energy rate being supplied to the engine actually decreased when considering the reduction in fuel lower heating value (LHV) observed in Table 5. It is not clear whether this increase in engine load might have an effect on the knockmeter measurements, and in the end of the RON rating of these fuels. 


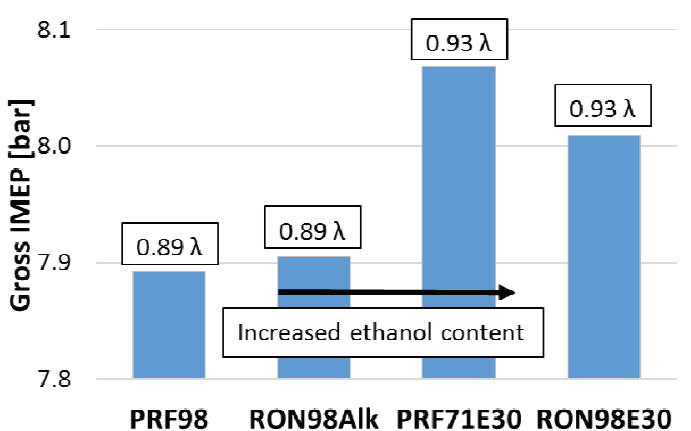

Fig. 4. Effect of fuel properties on engine load during RON testing

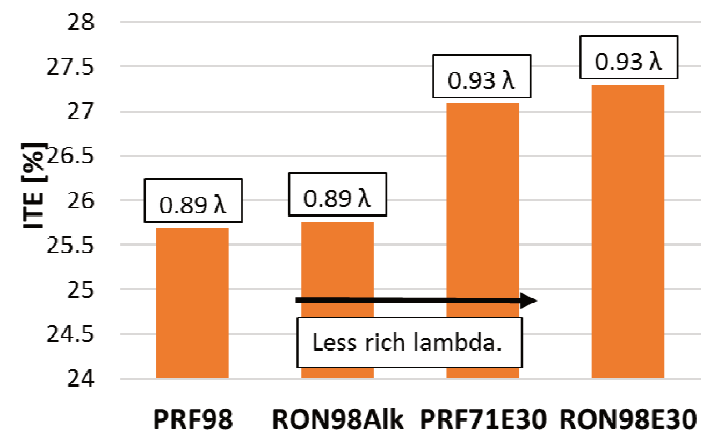

Fig. 5. Indicated thermal efficiency of each fuel at RON test conditions

As a result of the E30 fuels operating at peak knock closer to stoichiometry, the exhaust gas temperatures were also approximately $10^{\circ} \mathrm{C}$ higher, as can be seen in Fig. 6. It is likely that higher exhaust gas temperatures also caused a slight increase in cylinder residual gas temperature. Future work will look closer at how the combined effects of increased engine load and potentially increased residual gas temperatures may be possibly causing the E30 fuels to have their RON rating measured at more severe engine operating conditions than iso-paraffinic fuels with the same RON rating.

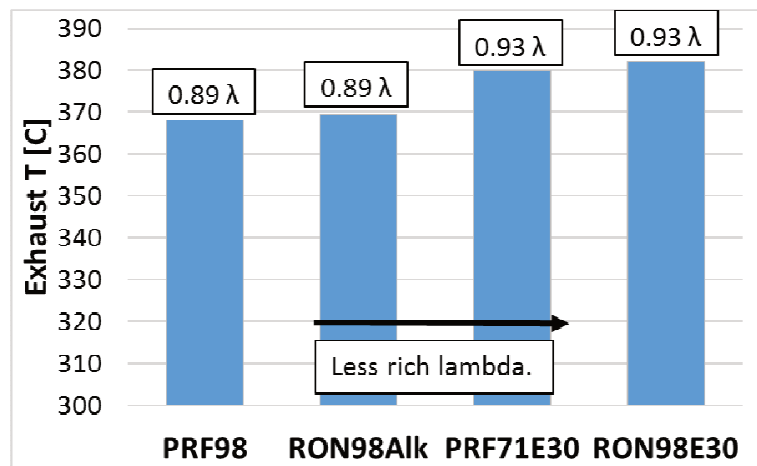

Fig. 6. Measured exhaust gas temperatures at RON conditions for each fuel

\subsection{Combustion characteristics at RON rating conditions}

Fig. 7 shows the different pressure-temperature trajectory cylinder conditions of each fuel from intake valve closing (IVC) to spark timing (ST). This plot was made using cylinder pressure data and an ideal gas law calculation of bulk gas temperature in AVL Concerto. Among the four fuels, the cylinder pressure from IVC to ST was very simi- lar. However, variations in charge cooling from the increased $\mathrm{HoV}$ of the E30 fuels caused them to have lower cylinder temperatures during compression. This difference in temperature between the fuels increased during compression, likely due to mixture gamma effects. This would suggest that during normal flame propagating combustion, prior to the onset of knock auto-ignition, the end gas temperatures of the E30 fuels would remain slightly lower than the iso-paraffinic fuels.

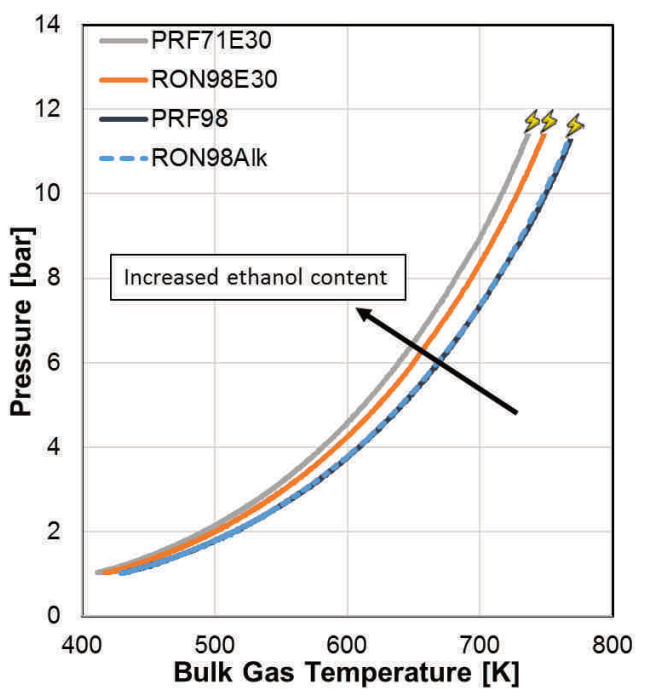

Fig. 7. Pressure-temperature trajectory from IVC to spark timing for each fuel at RON rating conditions

Fig. 8 shows cylinder pressure traces of each fuel under RON rating conditions from ST until shortly after the start of knocking combustion ringing. At the standard RON ST of $-13{ }^{\circ}$ aTDC, all fuels had roughly the same cylinder pressure near the end of compression. As seen in

Fig. 9, the start of combustion, denoted by the location of $10 \%$ mass fraction burned (CA10), is similarly just after firing top dead center (TDC) for all the fuels. The RON98E30 fuel achieved CA10 just slightly earlier than the other fuels. It has been shown that ethanol has a tendency to reduce the kernel development duration between ST and CA10 because of increased laminar flame speed $[8,9]$. It is not clear why the PRD71E30 did not have a similarly early CA10. One possible reason is that PRF71E30 had lower bulk gas temperatures at spark timing than RON98E30, as seen in Fig. 7.

Despite the similar CA10 timing of PRF71E30 as the iso-paraffinic fuels, the increased fuel laminar flame speed did cause its CA50 time to advance slightly. However, still not as advanced as the CA50 time of the RON98E30 fuel, which had the assistance of an earlier CA10 time.

The "knock-point" is a term developed by Swartz and is used to describe the location in the cylinder pressure trace where there is a sudden increase due to the auto-ignition of the fuel-air mixture in the end-gas. The timing of the knock-point was similar between the iso-paraffinic fuels, slightly advanced for the PRF71E30 (0.2-0.3 CAD), and even more advanced for the RON98E30 (another 0.6 CAD). It likely that the significant advance of the knockpoint for the RON98E30 is correlated with its lower RON 
rating. Additional testing with a small increase in ethanol content to match RON rating with the other fuels would likely provide similar combustion characteristics as the PRF71E30.

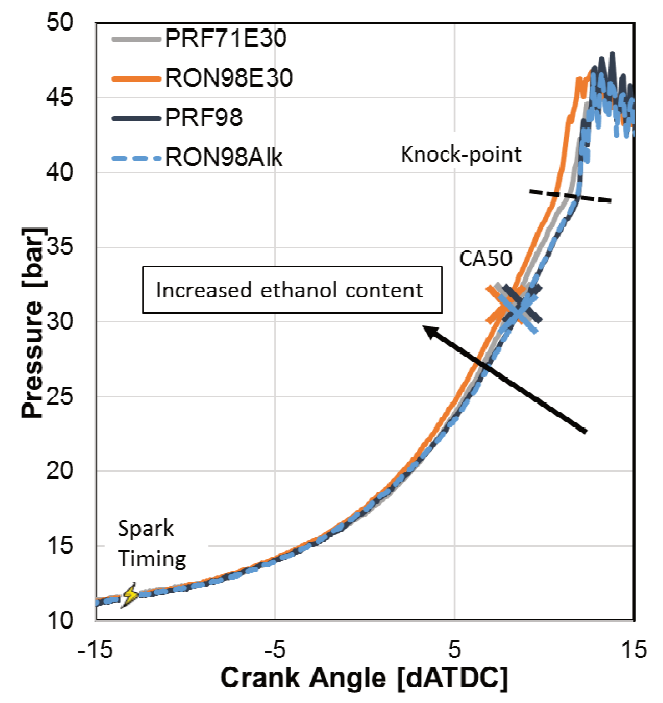

Fig. 8. Cylinder pressure from spark timing to combustion knock for each test fuel at RON rating conditions

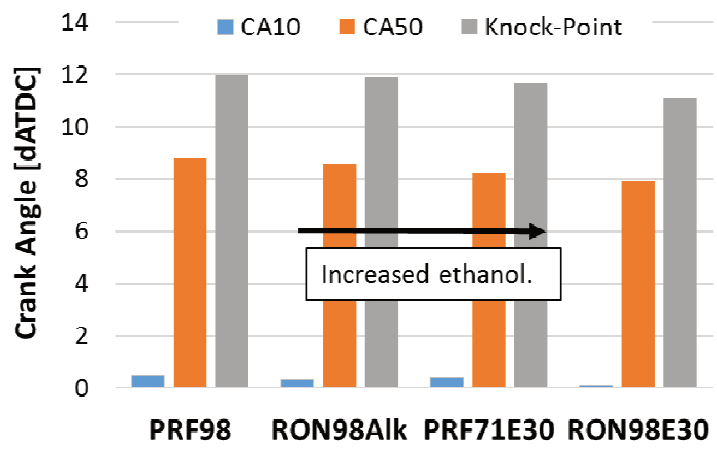

Fig. 9. Crankshaft angle position at 10\% mass fraction burned (CA10), $50 \%$ (CA50), and the knock-point for all fuels at RON rating conditions

It is also observed in Fig. 8 that the rate of pressure rise after the knock-point was higher for the iso-paraffinic fuels despite a later knock-point timing than the E30 fuels. Fig. 10 shows a closer look at the cylinder pressure data just after the knock-point. It is observed that not only do the E30 fuels have a weaker pressure rise rate, but they also had a lower peak to peak ringing intensity than the isoparaffinic fuels.

Fig. 11 shows a comparison of the ASTM knockmeter measurement against simultaneously measured peak pressure rise rates (PPRR) and knocking pressure peaks (KP_PK) using the spark plug cylinder pressure transducer. The advantage of the spark plug pressure transducer is that it allows simultaneous cylinder pressure measurement along with the ASTM knockmeter without any modifications to the cylinder head. The disadvantage is that it is not as accurate as a higher precision pressure transducer, such as the Kistler $6125 \mathrm{C}$, which has been used in lieu of the knockmeter pickup. A future study will look at comparing the cylinder pressure measurements between these two pressure transducers and perform measurements with these fuels and the higher resolution pressure transducer instead of the knockmeter pickup under RON rating conditions.

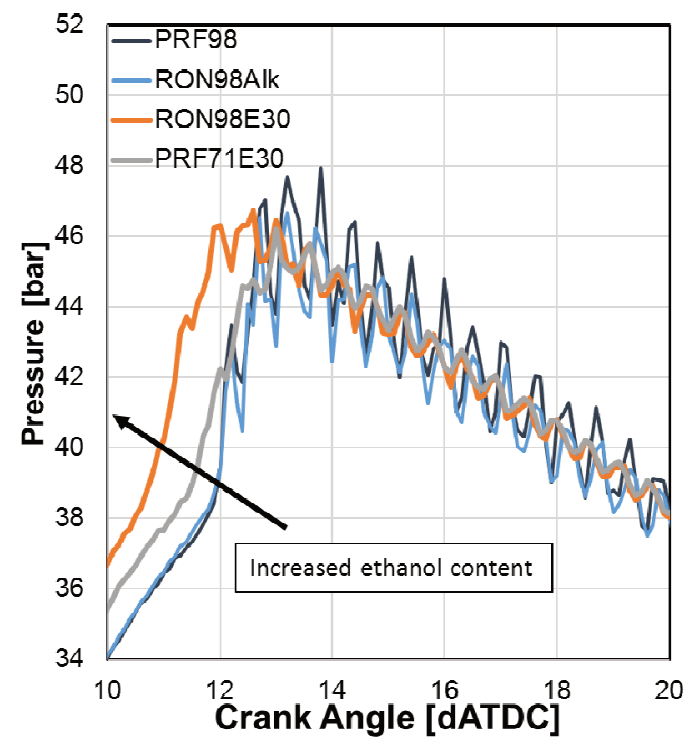

Fig. 10. Closer examination of the cylinder pressure behavior just after the knock-point

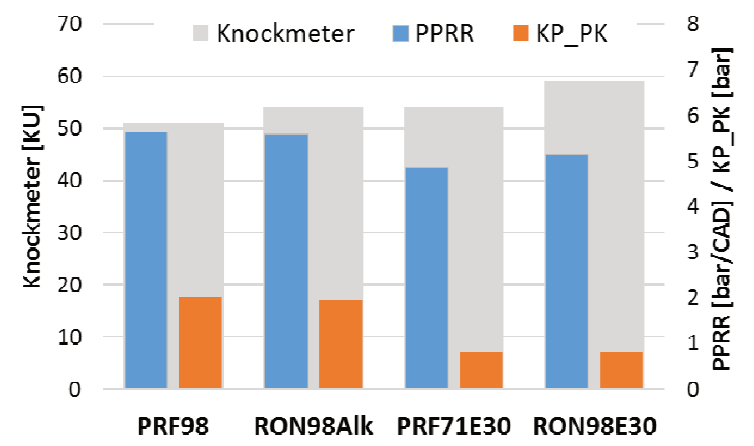

Fig. 11. Comparison of ASTM knockmeter measurement, peak pressure rise rate (PPRR), and knocking pressure peak (KP_PK)

Given that the modern knockmeter pickup is designed to replicate the older measurement of the bouncing pin, Swartz calculated that the knockmeter pickup measurement was mostly affected by the low frequency pressure rises, such as just after the knock-point $[10,11]$. The peak pressure rise rate was investigated as a proxy for the amplitude in the low frequency pressure oscillations expected to be best measured by the knockmeter pickup. As seen in Fig. 10 and Fig. 11, the E30 fuels had lower pressure rise after autoignition, but the knockmeter measurement was the same as the iso-paraffinic fuels, if not higher (RON98E30). In normal spark-ignition engines, it is the pressure ringing after the onset of knock that causes a reduction of the boundary layer and increased heat transfer to the combustion chamber surfaces [12]. This aspect of the pressure trace was analyzed by KP_PK. However there was not a correlation of KP_PK with knockmeter readings either. Therefore it is likely that the knockmeter pickup measurement is more complicated than the rate of pressure rise after the knockpoint or the ringing intensity. 


\section{Summary}

In this work, a highly instrumented Waukesha CFR F1/F2 engine was used to measure the effects of fuel property effects on engine operating conditions and combustion characteristics. Between two iso-paraffinic fuels of similar RON, there were few differences in the engine operating and cylinder conditions. However, significant differences were observed between the engine operating and cylinder conditions of the iso-paraffinic and fuel blends with $30 \% \mathrm{v}$ ethanol (E30) at the same (or similar) RON rating. The increased heat of vaporization $(\mathrm{HoV})$ of the E30 fuels caused a reduction in mixture temperature entering the engine and the cylinder temperatures at intake valve closing. These temperature reductions initially due to $\mathrm{HoV}$ were increased during compression, likely due to gamma differences between the mixtures. Most notably, the peak knocking lambda, where RON is measured, occurred at less rich conditions for the E30 fuels. This caused the RON rating of the E30 fuels to be performed at a more efficient engine operating condition with higher load and exhaust temperature. While the auto-ignition timing (knock-point) of the E30 fuels occurred earlier, the rate of pressure rise and the ringing intensity was much lower than for the iso-paraffinic fuels. Given that all of these fuels had a similar RON rating, it is not clear what characteristics of the cylinder pressure trace would best represent the ASTM knockmeter measurement.

\section{Acknowledgements}

This research was conducted as part of the CoOptimization of Fuels \& Engines (Co-Optima) project sponsored by the U.S. Department of Energy (DOE) Office of Energy Efficiency and Renewable Energy (EERE), Bioenergy Technologies and Vehicle Technologies Offices.

\section{Nomenclature}

${ }^{\circ}$ aTDC crank-angle degrees after firing top dead center

AKI anti-knock index

CA10 crank-angle of $10 \%$ mass fraction burned

CA50 crank-angle of 50\% mass fraction burned

CAD crank-angle degree

E30 $\quad 30 \%$ v ethanol

FR fuel rate

GDI gasoline direct injection

$\mathrm{HoV}$ heat of vaporization

IMEPg gross indicated mean effective pressure

IVC intake valve closing

KP_PK knock pressure peak

KU knock unit

$\begin{array}{ll}\text { LHV } & \text { lower heating value } \\ \text { MON } & \text { motor octane number } \\ \text { ON } & \text { octane number } \\ \text { PON } & \text { pump octane number } \\ \text { PPRR } & \text { peak pressure rise rate } \\ \text { PRF } & \text { primary reference fuel } \\ \text { RON } & \text { research octane number } \\ \text { rpm } & \text { revolutions per minute } \\ \text { SI } & \text { spark ignition } \\ \text { ST } & \text { spark timing } \\ \text { TDC } & \text { top dead center }\end{array}$

[7] FOONG, T.M., et al. Modeling end-gas autoignition of ethanol/gasoline surrogate blends in the cooperative fuel research engine. Energy Fuels. 2016.

[8] SZYBIST, J., SPLITTER, D. Effects of fuel composition on EGR dilution tolerance in spark ignited engines. SAE Int. J. Engines. 2016, 9(2).

[9] KOLODZIEJ, C., PAMMINGER, M., SEVIK, J. et al. Effects of fuel laminar flame speed compared to engine tumble ratio, ignition energy, and injection strategy on lean and EGR dilute spark ignition combustion. SAE Int. J. Fuels Lubr. 2017, 10(1), 2017-01-0671.

[10] YATES, A. et al. Insights relating to the autoignition characteristics of alcohol fuels Fuel. 2010, 89, 89-93.

[11] SWARTS, A. Insights relating to octane rating and the underlying role of autoignition. PhD thesis. Univ. of Cape Town, 2006.

[12] HEYWOOD, J.B. Internal combustion engine fundamentals. McGraw-Hill. NewYork 1988.

\footnotetext{
Thomas Wallner - Argonne National Laboratory,

USA.
} 